\title{
DANC: PASSADO, PRESENTE E FUTURO
}

DOI: $10.5380 /$ rmu.v2i2.42234

"Um povo que não preserva seu passado é um povo sem futuro". Resgatar a história do Diretório Acadêmico Nilo Cairo é motivo de muito orgulho e satisfação. História essa que completa 98 anos em dezembro e que se confunde com a do centenário Curso de Medicina da UFPR.

O DANC é, sem dúvida alguma, a mais tradicional instituição estudantil do Paraná e uma das maiores do país. Seu protagonismo foi evidenciado em diferentes momentos, tais como a federalização da UFPR e a construção do Hospital de Clínicas, a luta política pela redemocratização do país e a constituição do SUS. E já no ano de 2014, o DANC promoveu o Encontro Regional dos Estudantes de Medicina (EREM) em Curitiba.

Reunir e integrar os estudantes também era uma das características marcantes do DANC. Em seus tempos áureos, o prédio da Ébano Pereira - antiga sede do DANC- contava com restaurante, barbearia, gráfica e uma das boates mais badaladas de Curitiba e região. A vida social dos alunos acontecia e girava em torno do Diretório.

Contudo, o prestígio e a representatividade do DANC frente aos alunos de medicina da UFPR se perderam nos últimos anos. Prova disso foi o fato de termos ficado anos com chapa única concorrendo às eleições anuais do Diretório.

O desejo de mudar e, principalmente, de melhorar nos uniu e nos levou à construção de um projeto sólido e maduro. Os estudantes participaram de forma expressiva e obtivemos aproximadamente $85 \%$ dos votos dos mais de 700 participantes. Uma vitória que trouxe muita alegria, mas também responsabilidade e trabalho.

Estamos participando ativamente das reuniões departamentais, do colegiado do curso, do conselho setorial e do COAD. Mais do que isso, nossa voz tem sido ouvida e estamos reconquistando o respeito que esse diretório, quase centenário, merece.

Não deixando o engajamento político de lado, promovemos, já no nosso primeiro mês de gestão, um debate entre os alunos e os Ex-Diretores do DANC - Dr. Adriano Massuda e Dr. Alexandre Bley -, no qual discutimos o Projeto de Lei $(\mathrm{PL})$ 168/12. Tal projeto institui o serviço civil médico obrigatório. Os estudantes participaram em peso e a imensa maioria disse "não" a esse PL

Também iniciamos uma campanha "DANC: NÓS CONSTRUÍMOS" buscando arrecadação de fundos entre ex-alunos e professores a fim de viabilizar um espaço de convivência estudantil no Setor de Ciências da Saúde.

O resgaste científico e cultural do Diretório foi outro compromisso que assumimos. Iniciaremos, no segundo semestre, a realização de palestras e aulas com temas sugeridos em votação pelos alunos, Não poderíamos deixar de citar o enorme sucesso que foi o "Sarau do Nilo". Foi emocionante assistir a tantos colegas brilhando com seus diversos talentos. Temos prazer em dizer que a edição do segundo semestre já está sendo preparada. 


\section{EDITORIAL}

Sabemos que mudar nunca é fácil. Traz medo, insegurança, além de diversos questionamentos e dúvidas. Estamos nos empenhando ao máximo para realizar um trabalho que honre a história do Diretório e os mais de 1.100 alunos que representamos.

Nosso maior desafio é trazer os estudantes de volta para dentro do DANC. Um diretório sem estudantes é um diretório vazio e sem sentido. Contamos com o apoio e a participação dos nossos colegas para continuarmos a escrever essa história que tanto nos enche de orgulho.

Estamos Juntos! Juntos por mais Cem anos!

Victor José Dornelas Melo

Presidente do Diretório Acadêmico Nilo Cairo

Gestão "JUNTOS POR MAIS CEM ANOS"

1-Universidade Federal do Paraná

Contato do Autor / Mail to:

Victor Dornelas Melo - danc@danc.com.br

Rua General Carneiro, 181 - Alto da Glória Curitiba - PR, 80060-900, 10 Andar, Departamento de Clínica Médica 